\title{
Comparison of the Performance of Climbing Perch (Anabas testudineus Bloch) Filial 2 Fry and Natural Fry Treated in Acidic Swamp Waters, Jejangkit Village, South Kalimantan
}

\author{
Perbandingan Performa Ikan Papuyu (Anabas testudineus Bloch) Benih Filial 2 \\ dan Benih Alam yang Dibudidayakan di Perairan Rawa Masam \\ Desa Jejangkit Kalimantan Selatan

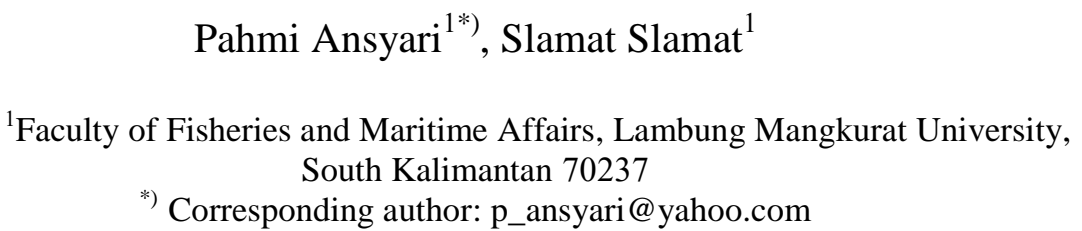

(Received: 18 September 2019, Accepted: 24 March 2020)

Citation: Ansyari F, Slamat S. 2020. Comparison of the performance of climbing perch (Anabas testudineus Bloch) filial 2 fry and natural fry treated in acidic swamp waters, Jejangkit Village, South Kalimantan. Jurnal Lahan Suboptimal: Journal of Suboptimal Lands 9(1): 23-30.

\begin{abstract}
ABSTRAK
Tujuan penelitian adalah membandingkan performance (tingkat kelangsungan hidup, pertumbuhan dan konversi pakan) benih ikan papuyu Filial 2 (F2) yang berkarakter unggul dengan benih alam yang dibudidayakan di perairan rawa masam. Penelitian dilaksanakan di perairan rawa, Desa Jejangkit, Kabupaten Barito Kuala, Kalimantan Selatan selama 6 bulan masa pemeliharaan (Januari s.d. Juni 2019). Studi ini membandingkan kinerja ikan yang dihasilkan dari benih F2 benih alam. Ikan dibudidayakan di hapa $4 \mathrm{~m}$ x $2 \mathrm{~m}$ x $1 \mathrm{~m}$ dengan padat penebaran yang sama yaitu $100 \mathrm{ekor} / \mathrm{m}^{2}$. Hasil penelitian menunjukkan bahwa tingkat kelangsungan hidup benih alam 86,6\% lebih tinggi dibanding benih F2 $75,3 \%$, tetapi pertumbuhan relatif benih alam $2.325 \%$ lebih rendah dibanding benih $\mathrm{F} 2$ $3.060 \%$ dan konversi pakan benih alam 3,03 kurang efisien dibanding benih F2 2,62. Disimpulkan performance benih F2 lebih baik dibanding benih alam, jika dipelihara di perairan rawa masam.
\end{abstract}

Kata kunci: performance, ikan papuyu, budidaya, perairan rawa masam

\begin{abstract}
The aim of the study was to compare the performance (survival rate, growth and feed conversion) of climbing perch fish fry Filial 2 (F2) which has superior characteristics with natural fry that are culture in sour swamp waters. The study was carried out in swamp waters, Jejangkit Village, Barito Kuala Regency, South Kalimantan for 6 months (January to June 2019). This study compared fish performances generated from F2 fry of nature. Fishes were cultured in net $(4 \mathrm{~m} \times 2 \mathrm{~m} \times 1 \mathrm{~m})$ with the same stocking density of 100 fishes $/ \mathrm{m}^{2}$. The results showed that the survival rate of natural fry was $86.6 \%$ higher than that of F2 75.3\%, but the relative growth of natural fry was 2,325\% lower than F2 3,060\% and feed conversion natural fry was 3.03 less efficient than F2 fry 2.62. It was concluded that the performance of F2 fry was better than natural fry, when maintained in acidic swamp waters.
\end{abstract}


Keywords: performance, climbing perch, culture, sour swamp waters

\section{INTRODUCTION}

One of the fisheries products that are classified as commercial and highly favored by the people of South Kalimantan is climbing perch (Anabas testudineus Bloch). This fish distribution is almost in all swamp waters, lake, reservoirs, rivers and other puddles. This fish can be caught throughout the year with the spawning season at the beginning of the rainy season. Efforts made by the community in meeting the needs of climbing perch mostly still rely on catches in nature compared to aquaculture. This has led to overfishing in the South Kalimantan public market, so that the number of climbing perch caught always decreases in size and size. According to Mackinnon et al. (2001), the swamp water ecosystem in South Kalimantan Province which reaches $+450,000$ ha is very possible to grow and develop various types of biota such as betok fish or papuyu which are typical exotic fish species in Banjar.The development of climbing perch in the direction of aquaculture has been included in the strategy plan for developing freshwater fish in South Kalimantan Province. This has shown results, as evidenced by Fisheries Households that grow climbing perch from year to year continues to increase. Even the Fisheries and Marine Faculty, Lambung Mangkurat University also plays a role, where now has found a superior character called the fry Filial 2 (F2) (Slamat, 2018). Currently climbing perch cultivation continues to be developed in South Kalimantan and is able to increase fish production every year from aquaculture activities. The cultivation of climbing perch in general is done by pond systems and biofloc systems, by maintaining excellent and controlled water quality.

In addition, South Kalimantan Province has a vast swamp waters of around 1 million ha. Swamp waters in South Kalimantan can be classified into three swamp ecosystems, namely: monotonous swamps found in Hulu Sungai Selatan District, Hulu Sungai Tengah and Hulu Sungai Utara; (2) rainfed swamps in Banjar and Barito Kuala Districts and (3) tidal swamps. Which is located in Tanah Laut, Tanah Bumbu, Pulau Laut and Barito Kuala Districts. From the swamp waters which is very problematic for life and fish culture media is rainfed swamp waters because the waters are acidic ( $\mathrm{pH}$ between 3.5-5). One of them is located in the swamp waters of Jejangkit Village, Barito Kuala Regency, South Kalimantan, which was the village where World Food Day was 2018 ago. This rainfed swamp waters (acid swamp) is part of sub optimal land which naturally has low productivity due to internal and external factors (Mulyani and Sarwani, 2013). Kalimantan is a potential area and can play a role in increasing fisheries production in Indonesia given that there are still many marginal lands that have not been utilized such as peatlands and other acid swamp waters (Anwar et al., 2010).

In order to take advantage of the vast acid swamp waters, it is necessary to study the utilization with the maintenance or cultivation of fish that are able to live and thrive in the aquatic environment, one of which is papuyu fish (Anabas testudineus Bloch). The study is to try to compare the performance of Filial 2 fry results from the research of the Fisheries and Marine Faculty, Lambung Mangkurat University with natural fry from the original habitat of acid swamp waters themselves. The purpose of this study was to compare the performance (survival rates, growth and feed conversion) of Filial 2 (F2) climbing perch fish fry that have superior character and natural seeds cultivated in acid swamp waters.

\section{MATERIALS AND METHODS}

This research was carried out in the rainfed swamp waters (acid) of Jejangkit 
Village, Jejangkit District, Barito Kuala Regency, South Kalimantan Province. Maintenance time trial for 6 (six) months from January to June 2019. The material used is in the form of fish fry size $1-3 \mathrm{~cm}$ with superior character (Filial-2) originating from the Wet Laboratory of the Fisheries and Maritime Faculty, Lambung Mangkurat University (ULM) and natural fry from the swamps of Jejangkit Village, which also measure 1-3 cm. While the feed used is CP Prima commercial feed produced by PT. Centra Proteina Prima Tbk with $28 \%$ protein. Feeding is done satiated with a frequency of 3 times a day, morning, afternoon and evening. Fry stocking density is 100 fries $/ \mathrm{m}^{2}$. Other equipment is in the form of hapa (the net) size $4 \mathrm{~m} \times 2 \mathrm{~m} \mathrm{x} 1 \mathrm{~m}$ as many as 6 (six) units, sampling equipment such as scoop, bucket, basin, scales, rulers and water sampling equipment such as sample bottles, $4 \%$ formalin and measuring equipment water quality, namely thermometer, $\mathrm{pH}$ meter, DO meter and ammonia test-kits.

This research is an action research study, in which in this study two trials were carried out, namely maintenance with Filial (F2) fry originating from the Wet Laboratory of the Fisheries and Marine Faculty, ULM and natural fry originating from the original habitat of the swamp waters of Jejangkit Village, Barito Kuala Regency. Test data analysis using $t$ test $(\mathrm{t}$ test) with an average difference test of 2 samples (Independent sample 2 test). The main parameters in this study are the Survival Rate, Absolute Growth, Relative Growth and Feed Conversion. Survival rates with equations (Effendie, 2002).

$S R=\mathrm{Nt} / \mathrm{NO}$

Remarks:

$\mathrm{SR}=$ Survival Rate $(\%)$

$\mathrm{N}_{0}=$ Numbers of stocking (individual)

$\mathrm{N}_{\mathrm{t}}=$ Numbers of harvest (individual)

Absolute growth uses the equation: $\mathrm{G}=\mathrm{Wt}-\mathrm{W} 0$;
Remarks:

$\mathrm{G}$ = Absoulute Growth (g);

$\mathrm{W}_{\mathrm{t}}=$ Weight of Harvest Population $(\mathrm{kg})$

$\mathrm{W}_{0}=$ Weight of Stocking Population $(\mathrm{kg})$

Relative Growth uses the equation:

$R G=(\mathrm{Wt}-\mathrm{W} 0) / \mathrm{W} 0$

Remarks:

$\mathrm{RG}=$ Relative Growth $(\%)$

$\mathrm{W}_{\mathrm{t}}=$ Weight of Harvest Population $(\mathrm{kg})$

$\mathrm{W}_{0}=$ Weight of Stocking Population $(\mathrm{kg})$

Feed Convertion Ratio uses the equation:

$F C R=\mathrm{F} /(\mathrm{Wt}-\mathrm{W} 0)$

Remarks:

FCR $=$ Feed Conversion Ratio

$\mathrm{F} \quad=$ Amount of feed given during fish rearing $(\mathrm{kg})$

$\mathrm{W}_{\mathrm{t}}=$ Weight of Harvest Population $(\mathrm{kg})$

$\mathrm{W}_{0}=$ Weight of Stocking Population $(\mathrm{kg})$

In addition to the main parameters above, measurement and analysis of supporting parameters is also carried out in the form of measurements of water quality parameters, namely water temperature, water $\mathrm{pH}$, dissolved oxygen and ammoniac nitrogen content.

\section{RESULT}

The survival rate of climbing perch for 6 months of maintenance in the village acid swamp Jejangkit, Barito Kuala Regency is presented in Table 1 and Figure 1.

Absolute growth $(\mathrm{g})$ and relative growth (\%) of climbing perch F2 fry and natural fry for 6 months of maintenance in the swamp waters of Jejangkit Village are presented in Table 2 and also presented in the form of graphs in Figure 2 and Figure 3.

The results of $\mathrm{F} 2$ climbing perch fry feed conversion and natural fry maintained by the hapa system for 6 months in the swamp waters of Jejangkit Village are presented in Table 3. 
Table 1. Survival rate of climbing perch for 6 months rearing periode (January to July 2019) in swamp waters, Jejangkit Village

\begin{tabular}{lcccc}
\hline \multirow{2}{*}{ Months } & \multicolumn{2}{c}{ Treatment A (F2 Fry) } & \multicolumn{2}{c}{ Treatment B (Nature Fry) } \\
\cline { 2 - 5 } & $\begin{array}{c}\text { Numbers of Fish } \\
\text { (Individual) }\end{array}$ & $\begin{array}{c}\text { Survival Rate } \\
(\%)\end{array}$ & $\begin{array}{c}\text { Numbers of Fish } \\
\text { (Individual) }\end{array}$ & $\begin{array}{c}\text { Survival Rate } \\
(\%)\end{array}$ \\
\hline January & 800 & 100.0 & 800 & 100.0 \\
February & 672 & 84.0 & 726 & 90.8 \\
March & 633 & 79.2 & 717 & 89.6 \\
April & 617 & 77.1 & 708 & 88.5 \\
May & 609 & 76.1 & 702 & 87.8 \\
June & 604 & 75.5 & 696 & 87.0 \\
July & 602 & 75.3 & 692 & 86.6 \\
\hline
\end{tabular}

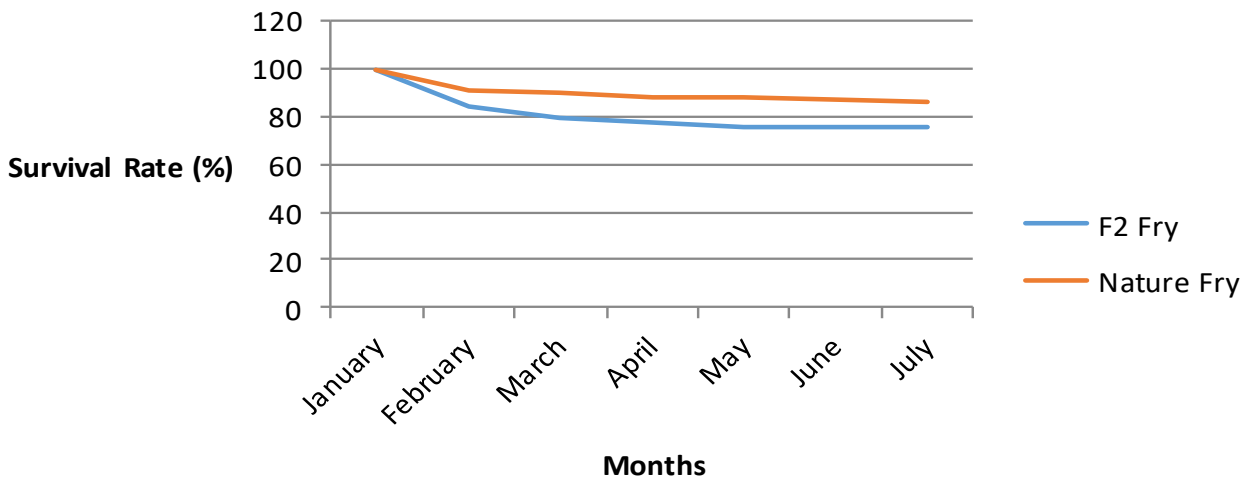

Figure 1. Survival Rate of climbing perch during 6 months rearing

Table 2. Growth of climbing perch for 6 months rearing periode (January to July 2019) with hapa system in swamp waters, Jejangkit Village

\begin{tabular}{lcccccc}
\hline \multirow{3}{*}{ Months } & \multicolumn{3}{c}{ Treatmen A (F2 Fry) } & \multicolumn{3}{c}{ Treatmen B (Nature Fry) } \\
& $\begin{array}{c}\text { Individual } \\
\text { Weight } \\
(\mathrm{g})\end{array}$ & $\begin{array}{c}\text { Absolute } \\
\text { Growth } \\
(\mathrm{g})\end{array}$ & $\begin{array}{c}\text { Relative } \\
\text { Growth } \\
(\%)\end{array}$ & $\begin{array}{c}\text { Individual } \\
\text { Weight } \\
(\mathrm{g})\end{array}$ & $\begin{array}{c}\text { Absolute } \\
\text { Growth } \\
(\mathrm{g})\end{array}$ & $\begin{array}{c}\text { Relative } \\
\text { Growth } \\
(\%)\end{array}$ \\
\hline January & 2.7 & 0 & 0 & 2.6 & 0 & 0 \\
February & 8.5 & 5.8 & 214.8 & 6.8 & 4.2 & 200.0 \\
March & 22.3 & 19.6 & 592.6 & 16.8 & 14.2 & 546.2 \\
April & 41.3 & 38.6 & 985.2 & 25.9 & 23.3 & 896.2 \\
May & 60.2 & 57.5 & 1.500 .0 & 37.3 & 34.7 & 1.334 .6 \\
June & 72.3 & 69.6 & 1.911 .1 & 49.9 & 47.3 & 1.819 .2 \\
July & 83.9 & 81.2 & 3.060 .0 & 63.0 & 63.0 & 2.325 .0 \\
\hline
\end{tabular}

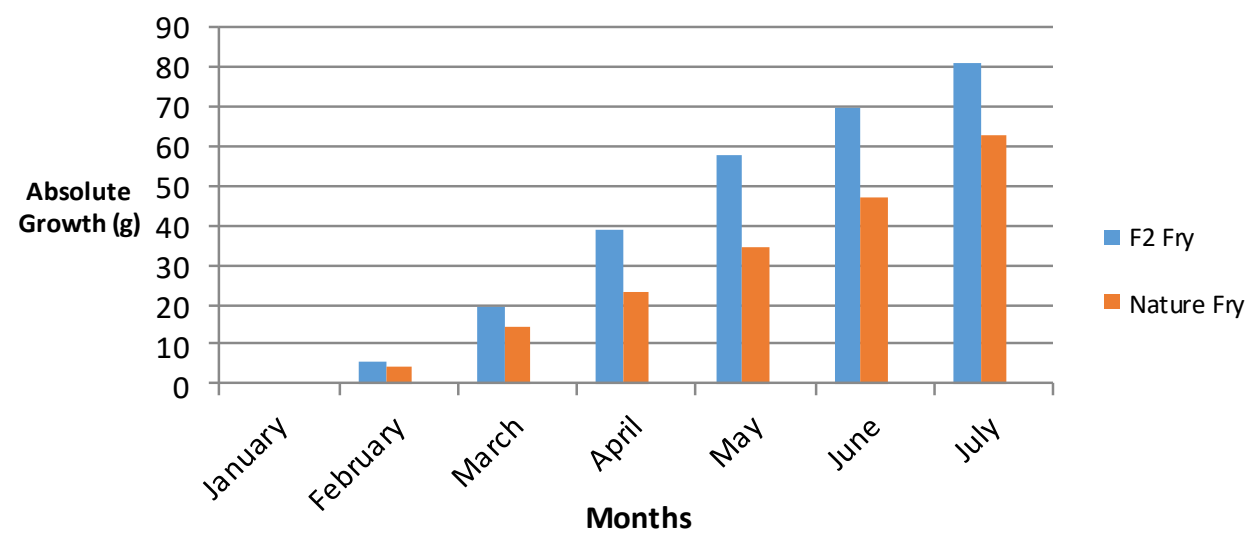

Figure 2. Graph of absolute growth of climbing perch for 6 months rearing 


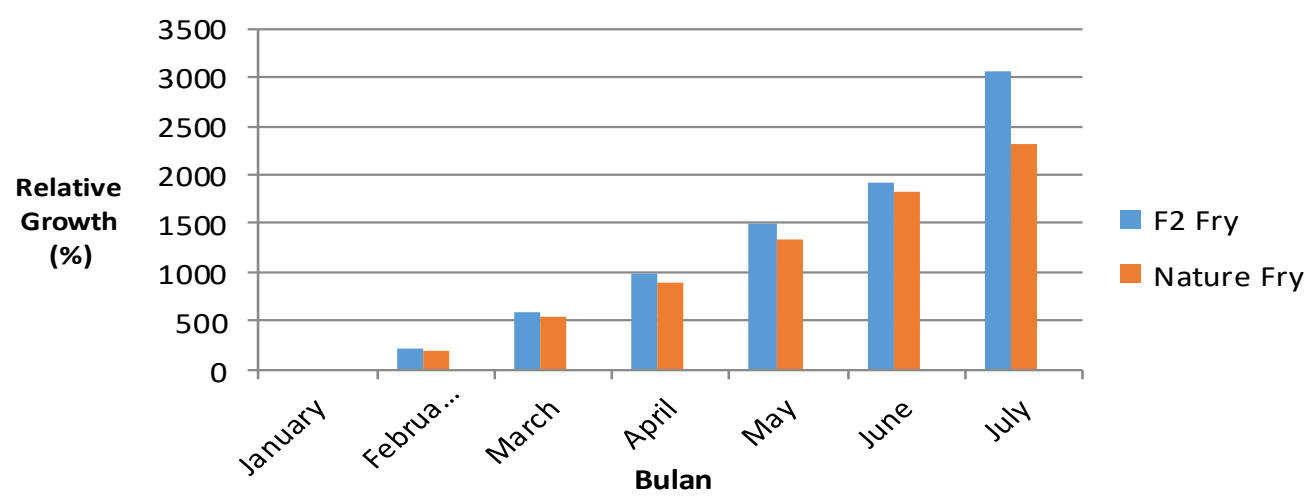

Figure 3. Graph of relative growth of climbing perch for 6 months rearing

Table 3. Feed convertion ratio of climbing perch reared in hapa system for 6 months periode (January to July 2019) in swamp waters, Jejangkit Village, Barito Kuala Regency

\begin{tabular}{lccccc}
\hline Treatment & $\begin{array}{c}\text { Weight of } \\
\text { Stocking } \\
\text { Population } \\
(\mathrm{g})\end{array}$ & $\begin{array}{c}\text { Weight of } \\
\text { Harvest } \\
\text { Population } \\
(\mathrm{g})\end{array}$ & $\begin{array}{c}\text { Gain of } \\
\text { Population } \\
\text { Weight } \\
(\mathrm{g})\end{array}$ & $\begin{array}{c}\text { Amount of Feed } \\
\text { Given } \\
(\mathrm{g})\end{array}$ & $\begin{array}{c}\text { Feed } \\
\text { Conversion } \\
\text { Ratio }\end{array}$ \\
\hline F2 Fry & 2.160 & $50,507.8$ & $48,347.8$ & $126,671.2$ & 2.62 \\
Nature Fry & 2.080 & $43,596.0$ & $41,516.0$ & $125,793.5$ & 3.03 \\
\hline
\end{tabular}

The results of measurements of several parameters of water quality in the swamps of Jejangkit village fish maintenance media
Climbing perch F2 fry and natural fry for 6 months are presented in Table 4.

Tabel 4. Parameters of water quality for 6 months periode (January to July 2019) in swamp waters, Jejangkit Village, Barito Kuala Regency.

\begin{tabular}{lcccc}
\hline \multirow{2}{*}{ Months } & \multicolumn{4}{c}{ Paramaters of Water Quality } \\
\cline { 2 - 5 } & $\begin{array}{c}\text { Temperature } \\
\left({ }^{\mathrm{O}} \mathrm{C}\right)\end{array}$ & Waters pH & $\begin{array}{c}\text { Dissolved } \\
\text { Oxygen }(\mathrm{mg} / \mathrm{l})\end{array}$ & $\begin{array}{c}\mathrm{NH}_{3}-\mathrm{N} \\
(\mathrm{mg} / \mathrm{l})\end{array}$ \\
\hline January & 25.5 & 3.6 & 3.6 & 0.06 \\
February & 26.0 & 3.6 & 3.5 & 0.05 \\
March & 26.0 & 3.8 & 4.0 & 0.05 \\
April & 26.5 & 4.0 & 4.1 & 0.05 \\
May & 27.0 & 4.1 & 4.1 & 0.04 \\
June & 27.0 & 4.1 & 4.2 & 0.04 \\
July & 28.0 & 4.2 & 4.0 & 0.04 \\
\hline
\end{tabular}

\section{DISCUSSION}

Survival rate is the ability of a fish population to survive during the maintenance period in the system and maintenance conditions. The survival rate of climbing perch during maintenance for F2 fry is $75.3 \%$ smaller than $86.6 \%$ natural fry. The results of this comparison show lower adaptation of F2 fry to acid swamp waters compared to natural fry.

However, survival rates that exceed $70 \%$ have shown good results. Even if seen from the monthly period graph, the fry experienced high mortality at the time of initial stocking, which shows that they are still in the adaptation phase. Comparison with research conducted by Miranti et al. (2017) the survival rate of climbing perch kept at $81.11 \%$.

Until the maintenance of 6 months (January to July 2019) papuyu fish with F2 fry, the absolute growth reached $81.2 \mathrm{~g}$ and the relative growth was $3,060.0 \%$ faster than the growth of natural fry fish, where the absolute growth was only $63.0 \mathrm{~g}$ and relative growth of $2,325.0 \%$. However, the growth of climbing perch tends to elongate 
first then followed by heavy growth (Slamat, 2012), which is referred to as negative allometric growth (Nordawati et al., 2019). The above proves that $\mathrm{F} 2$ fries are superior to natural fries in terms of growth and productivity, although the survival rate is lower.

According to Ansyari and Slamat (2017) F2 fry have the advantage of being aggressive in getting food, tame, adaptive and growing faster than others. F2 fries are also better able to utilize nutrients in their digestive metobolism, so they have low and efficient feed conversion. Furthermore, the results of Slamat et al. (2013) showed that the length and weight growth of climbing perch was more dominant as seen from the crossing of monotonous marshes with tides rather than tides and rainfed.

Some of the main factors that influence the dominance of the growth of climbing perch from monotonous swamps such as higher genetic diversity, better adaptation processes, large feed responses, benign and relatively resistant to extreme environmental changes. This has become the forerunner to climbing perch mother fish with superior character such as F2 fry.

According to Syulfia et al. (2015) who examined the enlargement of climbing perch with natural fry with $300 \mathrm{fry} / \mathrm{m}^{2}$ stocking and used seeds measuring $3-5 \mathrm{~cm}$ only obtained absolute growth of $2.27 \mathrm{~g}$ for 45 days and daily growth of $0.96 \%$. Furthermore Murjani (2011) examined the enlargement of several varieties of natural climbing perch fry originating from various types of marsh waters with the hapa system, where the varieties used were from rainfed swamp waters, monotonous swamps, tidal swamps and galam varieties.

The results showed that the four varieties were not significantly different in terms of growth and feed conversion. Hidayat et al. (2015) and Hidayat et al. (2016) obtained research results that climbing perch have sexual dimorphism related to growth. Growth of absolute weight and growth rate of daily weight of female fish were $48 \%$ and $17 \%$ higher $(\mathrm{p}<0.05)$ than male fish.
Thus the F2 seeds in this study are more female and male germination, so that growth is higher than natural seeds.

Feed conversion obtained from the results of this study is quite efficient; this is presumably due to the presence of high protein feed, which is $28 \%$. Comparison of F2 fry feed conversion with natural fry is quite significant, where the value of feed conversion for F2 fry is 2.62 and natural fry is 3.03. But overall the results of this study produce better feed conversion, compared to Murjani (2011), which get feed conversion of 5.50 for maintenance of climbing perch in swamp waters.

Suriansyah (2012), climbing perch need nutritious food with $28 \%$ protein which must be provided to increase their survival and growth. Furthermore Prasetya et al. (2016) said the large amount of feed used by fish has an impact on the adequacy and nutritional requirements needed by the body, so that it can growth and development.

The water quality measured for the $\mathrm{pH}$ parameters of the waters is very extreme, where measurements in January and February 2019 have an average value of only 3.6 , but continue to increase to 4.2 in July 2019. This is due to land washing, where the water in swamp waters has receded due to the dry season. However, extreme acidic waters are not a problem for the life and growth of climbing perch. According Uttam et al. (2005), climbing perch including Labirynthici fish, therefore it can live in waters that are relatively in poor condition. Even according to Maidie $e t$ al. (2015), climbing perch can be cultivated in rainwater media with oxygen saturation: $1.50 \%-47.4 \%$, oxygen solubility: $0.12-3.80$ $\mathrm{mg} / \mathrm{l}$, and $\mathrm{pH}: 3.45-5.85$.

It is commonly found in anabantidae families fish (including climbing perch) that live in swamp water, especially from the black fish group, have additional breathing apparatus (labyrinth) so that they can live in waters where oxygen is low and acidic (Utomo and Samuel, 2005 and Nordawati et al., 2019). Further said by Akbar (2017), 
climbing perch have a high tolerance to extreme environmental conditions for example acidic water conditions.

This fish can be found in lakes, rivers and swamps in Kalimantan which are known to have high acidity, characterized by low $\mathrm{pH}$. According Ernawati et al. (2009), swamps showed a decrease in $\mathrm{pH}$ and dissolved oxygen values but this did not significantly affect the survival of climbing perch.

Furthermore said by Slamat et al. (2018), climbing perch have a fairly wide tolerance to the aquatic environment, their habitats are mostly found in swamp waters with water that is brown or slightly blackish, such as in rice fields, small river banks, marshes with high acidity even up to brackish areas with salinity reaching 5 ppt.

According Huwoyon and Gustiano (2013), low pH (acid) is a major obstacle to the development of fish culture, so it is necessary to have a biological approach strategy by optimally utilizing the development of local fish, such as climbing perch and other swamp fish. Furthermore, for water quality parameters such as water temperature, dissolved oxygen and ammonia-nitrogen levels are at the desired quality standards in fish maintenance.

\section{CONCLUSION}

The F2 fry of climbing perch reared in acid swamp waters for 6 months produced an absolute growth of $81.2 \mathrm{~g}$ higher than natural fry which were only $63.0 \mathrm{~g}$. However, the F2 fry survival rate is $75.3 \%$ lower than the natural fry $86.6 \%$. Conversion of F2 fry feed 2.62 is better than natural fry 3.03. The results also show that the maintenance of climbing perch in acid swamp waters can be managed well and has the potential to be developed in the future.

\section{ACKNOWLEDGMENT}

Thank you to the Chancellor of University of Lambung Mangkurat (ULM) who has budgeted this research fund through the University PNBP in 2019. Thank you also to the Chairperson of Research Institutions and Community Service (LPPM) ULM, Dean of the Faculty of Fisheries and Marine ULM and Head of Department/Study Program of Aquaculture FPK ULM who has provided support and appreciation of this research.

\section{REFERENCES}

Akbar H. 2017. Ecobiology, Habitat and Potential of Betok Fish (Anabas testudineus Bloch) in Indonesia: Mini review. Aquaculture Study Program, Faculty of Agriculture, Samudra University, Langsa Aceh.

Anwar K, Tulus, Webby, Hasydi A, Rivai A. 2019. optimization of Climbing perch hatchery to increase productivity in peatlands. Paper on the Indonesian Aquaculture Society page.

Ansyari P, Slamat. 2017. Performance growth of papuyu fish based on filials F0, F1, F2, F3 and F4 in an effort to obtain seeds of superior character. Journal of Aquaculture Intek. 1(1): 55 62. ISSN: 2579-6291.

Effendie MI. 2002. Fisheries Biology. Publisher PT. Pustaka Nusantara Bogor Foundation Publisher.

Ernawati Y, Kamal MM, Pellokila NAY. 2009. Reproductive biology of the Climbing perch (Anabas testudineus Bloch) in the swamp of the Mahakam River, East Kalimantan. Indonesian Iktiologi Journal. 9(2): 113 - 127.

Hidayat R, Charman O, Alimuddin. 2015. Evaluation of growth in determining sex differentiation and functional male papuyu (Anabas testudineus Bloch) fish production. Aquaculture Science Study Program, Faculty of Fisheries and Marine Sciences, Bogor Agricultural University.

Hidayat R, Charman O, Alimuddin. 2016. Differences in growth of male and female Climbing perch (Anabas testudineus Bloch). Indonesian 
Aquaculture Journal. 15 (1): 8-14. DOI: 10.19027 / jai.15.8.14.

Huwoyon GH, Gustiano R. 2013. Increased productivity of fish farming in Peatlands. Journal of Aquaculture Media. 8(1): 2013.

Maidie A, Sumoharjo, Asra SW, Ramadhan M, Hidayanto DN. 2015. The Development of Betabies (Anabas testudineus) Hatchery for Household Scale. Journal of Aquaculture Media. 10 (1): 31-37.

Mackinnon K, Hatta GM, Halim H, Mangalik A. 2001. Kalimantan Ecology. Prenhalindo, Jakarta. 800-806 pages.

Miranti F, Muslim, Yulisman. 2017. Growth and survival of the larvae of the betok fish (Anabas testudineus Bloch) which are exposed to different lengths of time. Indonesian Swamp Aquaculture Journal. 5(1): 33-44. ISSN: 2303 - 2960.

Mulyani A, Sarwani M. 2013. Characteristics and sub-optimal land potential for agricultural development in Indonesia. Land Resource Journal. 7 (1). ISSN: 1907-0799.

Murjani A. 2011. Growth performance of several varieties of Betok fish (Anabas testudineus Bloch) that are kept in swamp waters. Chlorophyl Agricultural Scientific Journal. 7 (2): 305-371. ISSN: 1858 - 3954.

Nordawati S, Fahmi Z, Supriadi F. 2019. Parameter of Betok Popoulasi (Anabas testudineus Bloch) in the Musi River Flood Exposure ecosystem. Biology News, Journal of Life Sciences. LIPI. 18 (1): April 2019, P-ISSN: 0126-1754; EISSN: 2337-8751, Accredited Rank 2.

Prasetya AB, Suriansyah, Rosita, Bugar H. 2016. Growth of the larvae of the fish (Anabas testudineus Bloch) with natural feed. Journal of Tropical Animal Sciences. 5 (2): December 2016. Pages: unkripjournal.cpm. ISSN: 2301-7783.

Slamat. 2012. Genetic conservation of fish in three types of swamp waters ecosystem in South Kalimantan. Indonesian Fisheries Research Journal. March 2012 edition.

Slamat, Rini KR, Fatmawati, Rukmini, Fauzana NA. 2013. Appropriate Technology for Betok Fish Hatchery. Faculty of Fisheries, Lambung Mangkurat University. 70 pages.

Slamat, Rina RK, Ansyari P. 2017. Breeding papuyu anabas testudineus bloch with phylogenetic meristic hybridization techniques from three types of swamp water ecosystems. Journal of Aquaculture Intek. 1 (2): 7989.

Slamat, Krisdianto, Ansyari P. 2018. Bioecology and reproduction of the female fish (Anabas testudineus Bloch 1792) in the monotonous swamp. Publisher Muhammadiyah Banjarmasin University Press. ISBN: 978-602-52037$0-1$.

Suriansyah. 2012. The survival of the fish larvae (Anabas testudineus Bloch) by Giving Natural Feeds from Fertilization in Peat Water Media. Journal of Tropical Animal Sciences. 1 (2): December 2012.

Syulfia R, Putra I, Rusliadi. 2015. The growth and graduation of live fish (Anabas testudineus Bloch) with different stocking densities. Student Thesis, Faculty of Fisheries and Marine Sciences, Riau University.

Uttam S, Deepak PK, Kapoor D, Singh RN, Kumar SP, Singh S. 2005. Captive Breeding of Climbing Perch (Anabas testudineus Bloch 1992) woth Wova-FH for Conservation and aquaculture. Journal of Aquaculture Research. 36: $941-945$.

Utomo, Samuel. 2005. Status of fish diversity in public waters. Proceedings of the Indonesian Public Water Forum. BRKP - DKP. 465 things. 